\title{
The Role of Life History Traits for Bryophyte Community Patterns in Two Contrasting Alpine Regions
}

\author{
GunNar Austrheim AND Kristian Hassel \\ Department of Biology, Norwegian University of Science and Technology, N-7491 Trondheim, Norway; e-mail: \\ Gunnar.Austrheim@bio.ntnu.no
}

\section{AtLe Mysterud}

Centre for Ecological and Evolutionary Synthesis (CEES), Department of Biology, University of Oslo, P.O. Box 1066 Blindern, N-0316 Oslo, Norway

\begin{abstract}
Bryophytes are an important plant group with long-term dominance in alpine habitats. The alpine environment is however severe, and may restrict variation in bryophyte life history. This study examines the relationship between frequencies of bryophyte species and their life history traits between and within two alpine environments that differ in important environmental variables identified for bryophytes: 1) an oceanic region, with humid acidic soils (Setesdal) and 2) a sub-continental region, with more dry, productive, base-rich soils (Hol). A comparison between regions showed a higher frequency of base-demanding bryophytes in the sub-continental region. Sexual reproduction was more common among bryophytes in the oceanic region and these species also had higher indicator values for oceanic conditions and temperature as expected. Several life history traits were strongly correlated with bryophyte frequencies in the oceanic region-local species abundance increased in relation to shoot longevity, dioicism (mainly vegetative reproduction), and high humidity indicator values, but decreased for species with asexual propagules (gemmae). No traits were correlated with bryophyte frequencies in the sub-continental region. The importance of life history traits in the oceanic region indicates that severe environmental factors override bryophyte community heterogeneity only in the oceanic, acidic region. A possible explanation for higher environmental stress favoring tolerant long-lived species with vegetative reproduction could be higher grazing pressure, which is also reflected in significantly lower cryptogam coverage and correspondingly larger area of open soil in the oceanic region.
\end{abstract}

Keywords. Local abundance, oceanic conditions, pH, regional distribution, soil moisture, subcontinentality.

Plant species traits and abundances can change dramatically along environmental gradients. According to classical niche theory, these plant abundance patterns are niche separations due to differences in competitive interactions among species (Hutchinson 1957). In habitats with high variation in abiotic and biotic factors, environmental heterogeneity is expected to balance abundance among different plant life histories with no preferences for species expressing specific traits. However, in habitats where one or a few severe environmental factors (extreme climate, intensive grazing) override the effects of other environmental variation, plants with an ability to tolerate stress or disturbance due to specific traits are expected to dominate (Grime 1979; Reader 1998; Westoby et al. 1997). The probability of detecting relationships between plant species abundance and their life history traits is expected to increase with the duration of plant-environment interactions (Brown 1995).
Bryophytes show long-term dominance in some alpine/tundra environments and peatlands where competition for light from higher plants is low or absent (Bates 1998). The suitability of alpine habitats is also indicated by the high diversity of bryophytes in alpine habitats, and $39 \%$ and $44 \%$ of all bryophytes occurring in, respectively, Norway and Sweden are found above tree line (Frisvoll 1996; Hallingbäck 1996). However, plants in the alpine region experience severe environmental conditions with a limited growing season, low temperature extremes, and freezing and thawing, in addition to grazing (Heegaard 2002; Körner 1999; Longton 1988). The alpine environment is expected to restrict the main life history strategies for the alpine bryophyte species pool, and affect abundance patterns within a community. In a comparison between alpine and lowland populations of Pogonatum dentatum, Hassel et al. (2005) found higher vegetative growth and lower sexual reproductive investment 
for alpine populations, and alpine females tended to reach maturity later as compared to lowland populations. Recruitment from spores was also higher in the lowland population. Hence, it could be predicted that the alpine species pools and communities would be dominated by bryophytes able to tolerate environmental stress such as perennial stayers or long-lived shuttle species (see During 1992) and species with a low probability of sexual reproduction. If sexual reproduction is important, species with large spores are expected to have an advantage at the local scale (equivalent to the importance of seed weight for seed plants, Moles \& Westoby 2002). However, the composition of bryophyte species pools also varies among alpine regions. According to Störmer (1969), climatic factors are the most important in explaining large scale differences in species pools between oceanic and continental regions, and Gignac et al. (1991) showed that climate (hyperoceanic to sub-continental) was an important factor influencing the bryophyte component of peatland vegetation in western Canada. Substrate $\mathrm{pH}$ is another important factor for structuring bryophytes at larger scales, and Bates (1995) found varying affinity to base-rich substrate to be the main factor for explaining bryophyte species patterns in Berkshire, England.

Although indicator values for species-specific affinities to important ecological variables are given for most European bryophytes (Düll 1991; Ellenberg 1991), quantitative measurements of life history traits are limited. The identification of important traits and the predicted relationships among traits are, however, well established. During (1992) suggested six main life history strategies for bryophytes using longevity, reproductive effort, and spore number and size as the main traits. His classification is further based on three important tradeoffs: 1) few large spores versus many small spores, 2) survival of the difficult season as spores only (avoidance) versus survival of the gametophore (tolerance), and 3) for the tolerance group, potential life span of the gametophore versus reproductive investment. However, there are few studies on the functional importance of traits for bryophyte community patterns. Vanderpoorten and Engels (2002) examined the importance of (mainly qualitative) traits, and found spore size, longevity, growth-form type, and papillose leaf cells to be significantly correlated with species predictability for bryophyte distributions on a regional scale in Belgium. Most bryophytes had an increased predictability with forest cover $(55 \%)$, while only $4 \%$ occurred on open land and had a distribution that could be predicted.

This study examines the relationship between local abundance of bryophyte species (small-scale frequency) and regional distribution (landscape scale frequency), and their life history traits between and within two alpine environments in southern Norway that differ in some of the most important environmental variables identified for bryophytes. Setesdal is in an oceanic region, with humid acidic soils, while $\mathrm{Hol}$ is in a sub-continental region, with more dry and base-rich soils. The following predictions are addressed: 1a) We expect bryophyte frequencies to be positively correlated with traits reflecting habitat severity (e.g., longevity) and negatively correlated to sexual reproduction in both regions. An additional environmental stress such as grazing that occurs in both regions, is expected to strengthen these relationships with preferences for long-lived tolerant species having mainly vegetative reproduction. 1b) Alternatively, grazing might increase diaspore recruitment (During 1992). Hence, an increased frequency of colonists and short-lived shuttle species, depending on sexual reproduction or presence of gemmae, is a probable alternative prediction. 2) We expect higher bryophyte richness and frequencies of base indicators in Hol, and indicators of oceanicity and humidity in Setesdal. The relationship between environmental variables and bryophyte trait patterns is less obvious. 3) We expect a higher number of liverworts and Sphagnum species in Setesdal due to higher precipitation. 4) Oceanic conditions are expected to favor sexual reproduction (which depends on water; Longton \& Schuster 1983), while bryophytes with a papillose leaf cell wall (promoting drought resistance) should be more frequent in subcontinental areas with less precipitation.

\section{Materials AND Methods}

Study sites.-Both study sites are located in the alpine region in southern Norway. Hol, in the county of Buskerud, $\left(60^{\circ} 40^{\prime} \mathrm{N}, 7^{\circ} 55^{\prime} \mathrm{E}\right)$ has a sub-continental climate, with a mean annual precipitation of 700-800 mm (Førland 1993). The bedrock consists of metaarkose (Sigmond 1998) that gives rise to moderately base-rich soils, especially in landscape depressions with seepage water. The Setesdal site includes parts of two counties (Vest-Agder and Aust-Agder) at $58^{\circ} 59^{\prime} \mathrm{N}, 6^{\circ} 58^{\prime} \mathrm{E}$ in SW Norway, and has a more oceanic climate with a high annual precipitation (950-1,650 mm). The bedrock is Precambrian granite that is resistant to weathering and gives rise to acidic mineral soils that are poor in nutrients (Holtedahl 1969). Both sites have been grazed occasionally by wild reindeer (Rangifer tarandus) and more intensively by domestic sheep (Ovis aries). Sheep densities reached ca $20-50$ per $\mathrm{km}^{2}$ in Setesdal and ca 10 per $\mathrm{km}^{2}$ in $\mathrm{Hol}$ in 2001.

Bryophyte community and environmental data.-Bryophyte frequencies from Hol were sampled in 2001 in 180 plots $\left(0.25 \mathrm{~m}^{2}\right.$ each $)$, randomly chosen within an alpine area of ca $2.7 \mathrm{~km}^{2}$, but with a balanced stratified distribution among habitats and altitudinal levels (between ca 1,050-1,250 m a.s.1.). Bryophyte frequencies from Setesdal were sampled in 2000 at 10 different sites $(0.2$ ha each) with a balanced stratified distribution within an area of ca $124 \mathrm{~km}^{2}$ at ca $900-1,000 \mathrm{~m}$ a.s.l. Twenty plots $(0.25$ 
TABLE 1. Life history traits included as explanatory variables. Bryophytes and their respective trait values are given in Appendix 1.

\begin{tabular}{|c|c|c|}
\hline Variables & Classes & Comment/References \\
\hline Growth form & $\begin{array}{l}\text { 1) Liverworts, 2) Acrocarpous } \\
\text { growing mosses, 3) Pleurocar- } \\
\text { pous, and 4) Sphagnum mosses }\end{array}$ & \\
\hline Life-history strategies & $\begin{array}{l}\text { 1) Colonists, 2) Colonist pioneer, 3) } \\
\text { Perennial stayer competitive, 4) } \\
\text { Perennial stayer stress tolerant, 5) } \\
\text { Short-lived shuttle, and 6) Long- } \\
\text { lived shuttle }\end{array}$ & During 1992, Frisvoll 1997 \\
\hline Sexuality & 1) Monoicous and 2) Dioicous & $\begin{array}{l}\text { Damsholt 2002, Nyholm 1987, } 1989 \text {, } \\
\text { 1993, 1998, Smith } 1978\end{array}$ \\
\hline Longevity & $\begin{array}{l}\text { 1) Short-lived }(<5 \text { yr. }) \text { and } 2) \\
\text { Long-lived }(>5 \text { yr. })\end{array}$ & $\begin{array}{l}\text { According to life history strategy classifi- } \\
\text { cation. }\end{array}$ \\
\hline Sexual reproduction & 1) Uncommon and 2) Common & $\begin{array}{l}\text { Damsholt 2002, Nyholm 1987, 1989, } \\
\text { 1993, 1998, Smith } 1978\end{array}$ \\
\hline Spore size (diameter $\mu \mathrm{m}$ ) & $\mathrm{Nm}$ (interval data) & $\begin{array}{l}\text { Damsholt 2002, Nyholm 1987, 1989, } \\
\text { 1993, 1998, Smith } 1978\end{array}$ \\
\hline Gemmae & 0) Not known and 1) Known & $\begin{array}{l}\text { Damsholt 2002, Nyholm 1987, 1989, } \\
\text { 1993, 1998, Smith } 1978\end{array}$ \\
\hline Papillose leaf cell walls & 0) No and 1) Yes & $\begin{array}{l}\text { Damsholt 2002, Nyholm 1987, 1989, } \\
\text { 1993, 1998, Smith } 1978\end{array}$ \\
\hline Light demands & $\begin{array}{l}\text { Scale from } 1 \text { (dark) to } 10 \text { (open } \\
\text { light) }\end{array}$ & $\begin{array}{l}\text { Düll 1991, Ellenberg et al. 1991, Vevle } \\
1999\end{array}$ \\
\hline Temperature demand & Scale from 1 (cold) to 10 (warm) & $\begin{array}{l}\text { Düll 1991, Ellenberg et al. 1991, Vevle } \\
1999\end{array}$ \\
\hline Soil moisture demand & Scale from 1 (dry) to 10 (humid) & $\begin{array}{l}\text { Düll 1991, Ellenberg et al. 1991, Vevle } \\
1999\end{array}$ \\
\hline Oceanic-continental & $\begin{array}{l}\text { Scale from } 1 \text { (oceanic) to } 10 \text { (conti- } \\
\text { nental) }\end{array}$ & $\begin{array}{l}\text { Düll 1991, Ellenberg et al. 1991, Vevle } \\
1999\end{array}$ \\
\hline Acidic-basic demands & Scale from 1 (acidic) to 10 (basic) & $\begin{array}{l}\text { Düll 1991, Ellenberg et al. 1991, Vevle } \\
1999\end{array}$ \\
\hline
\end{tabular}

$\mathrm{m}^{2}$ ) were established randomly at each site (total of 200 plots). Plant species frequencies in all plots are based on presence-absence within 16 subplots $\left(0.0156 \mathrm{~m}^{2}\right)$. All plots in both regions were placed at southerly exposed sites spanning the topography-snow cover gradient from ridge, via lee-side to moderate and late snow patches. Peatland habitats and plots with more than $10 \%$ cover of bedrock and stones were excluded. The bryophyte frequency data are expressed at both a local and a regional scale. Local abundance denotes mean frequency in all plots where the species occur. Regional distribution denotes percent plots where the species is present in relation to the total number of plots within each region. Species nomenclature follows Frisvoll et al. (1995).

A specification of the environment is given by vascular plant cover $(\%)$ and height, cryptogam cover (\%), and open soil area (\%), in addition to soil environmental data [pH, loss on ignition (LOI), dry matter (DM), phosphorus $(\mathrm{P})$, potassium $(\mathrm{K})$, calcium $(\mathrm{Ca})$, magnesium $(\mathrm{Mg})$, and sodium (Na)] in each plot. All soil analyses follow international standards (Krogstad 1992) and were performed at the Norwegian Centre for Soil and Environmental Research (Jordforsk) except for LOI and DM that were performed at Department of Biology, University of Oslo.

Life history traits. - Thirteen different traits were included as explanatory variables in the analysis of bryophyte abundance and distribution patterns (Table 1). The species were divided into classes according to their main life history strategies (focusing on gametophore longevity and spore size), traits important for sexual (sexuality, frequency of sexual reproduction, spore size), and clonal reproduction (ability of specialised asexual reproduction), and morphological traits (growth form, and cell papillosity). We also used bryophyte indicator values based on phytosociological and ecological information (Düll 1991; Ellenberg 1991) and with a focus on species demands for light, temperature, soil humidity, base-richness in soil, and oceanic conditions (see Table 1 for references and comments and a more specific description of each trait).

Data analysis. - Since several bryophytes occurred in both habitats, each region was treated as a separate data set to avoid pseudoreplication. A $t$-test was used for examining differences in bryophyte community patterns and life history traits between species pools in each region. We used linear regression to detect relationships between bryophyte frequencies (local abundance and regional distribution) and continuous (spore size) and discrete explanatory variables (ecological indicator values for light, temperature, oceanic conditions, soil humidity, and acidity) within each region. The effects of categorical variables (longevity, sexual reproduction, gemmae, sexuality, and the occurrence of papillose leaf cell walls) on bryophyte frequencies were analyzed with ANOVA. Both continuous and categorical variables were included in a stepwise multiple linear model with backward elimination. We searched for collinearity among traits prior to the multiple analyses. Spearman's rank correlation was used for analyses involving ordinal data (both continuous and discrete), while correlation coefficients for dichotomous nominal data are based on Ives and Gibbons (1967) using a chisquare significance test with corrections for continuity (Yates 1934). Bryophyte frequencies were arcsine transformed prior to the analysis. Spore size values were lntransformed to stabilize the variance. Analyses were per- 
TABLE 2. (A) Life-history strategy frequency (\%) and number of species (in parentheses) within each regional species pool. (B) Growth-form type frequency (\%) and number of species (in parentheses) within each regional species pool.

\begin{tabular}{lcc}
\hline \hline A & Hol & Setesdal \\
\hline Colonist & $12(7)$ & $18(9)$ \\
Colonist pioneer & $14(8)$ & $16(8)$ \\
Perennial stayer; competitive & $34(20)$ & $29(15)$ \\
Perennial stayer; stress tolerant & $19(11)$ & $12(6)$ \\
Short-lived shuttle & $2(1)$ & $0(0)$ \\
Long-lived shuttle & $16(9)$ & $20(10)$ \\
Species spp. & $3(2)$ & $6(3)$ \\
B & & \\
& Hol & Setesdal \\
\hline Liverworts & $33(19)$ & $35(18)$ \\
Acrocarpous mosses & $31(18)$ & $29(15)$ \\
Pleurocarpous mosses & $31(18)$ & $24(12)$ \\
Sphagnum mosses & $5(3)$ & $12(6)$ \\
\hline
\end{tabular}

formed in S-Plus vs. 6.1. when no other software is specified.

All plant traits are evolutionarily based, and bryophyte trait-frequency correlations could be an effect of common ancestry among bryophytes. We therefore tested for possible phylogenetic effects by calculating a set of phylogenetic independent contrasts (Harvey \& Pagel 1991) for all traits in each bryophyte community using the program COMPARE (Martins 2003). To build a phylogenetic tree of the bryophytes included in this study is not straightforward, as there still is much ambiguity in the classification of bryophytes (Shaw \& Goffinet 2000). The constructed trees are based on current molecular and morphological information available (Crandall-Stotler \& Stotler (2000) and Grolle \& Long (2000) for the liverworts; Buck \& Goffinet (2000), Cox et al. (2000), De Luna et al. (2000), La Farge et al. (2000), Newton et al. (2000), and Shaw (2000) for the mosses.

\section{RESUlts}

Bryophyte community patterns and life history traits between region comparison.-The discrep- ancies in species richness between regions were low. The total bryophyte species pool on sub-continental base rich soils (Hol) included 58 bryophytes, while 51 bryophytes were found on oceanic acidic soils (Setesdal). Species richness at the small-scale $\left(0.25 \mathrm{~m}^{2}\right)$ was 6.79 (S.E. \pm 1.91$)$ at Setesdal and 7.57 (S.E. \pm 2.28 ) at Hol. Only 25 species were found in both regions. Thirty-three species were unique for Hol, while 26 species were unique for Setesdal.

Both regions were dominated by long-lived bryophytes (Table 2a). Perennial stayers (both competitive and stress tolerant) and long-lived shuttle species represented $69 \%$ and $61 \%$ of the Hol and Setesdal species pool respectively. Species richness was surprisingly even among liverworts, acrocarpous, and pleurocarpous mosses, and each growthform type represented approximately $1 / 3$ of the total species pool in both regions (Table 2b). Sphagnum mosses constituted $5 \%$ at $\mathrm{Hol}$ and $12 \%$ at Setesdal, respectively. The number of base-indicating species was also higher in Hol $(t=3.36$, df $=96$, $p=0.001)$, while Setesdal had more oceanic species $(t=2.32$, df $=92, p=0.023)$ and species with higher temperature demands $(t=2.01$, df $=$ $85, p=0.048$ ) as compared to Hol. Sexual reproduction was more common for species in Setesdal, as compared to Hol $(t=-2.02$, df $=100, p=$ 0.045).

Cryptogam cover (mainly bryophytes, but lichens are also included) was significantly denser at Hol, which also had a significantly lower open soil area compared to Setesdal. Plant community samples at Setesdal had significantly denser and higher vascular plant cover as compared to Hol, while vascular plant diversity was significantly higher at Hol (Table 3A). Soil samples showed a higher $\mathrm{pH}$ level at Hol (4.45 \pm 0.37$)$ as compared to Setesdal (4.41

TABLE 3. Environmental variables (mean values \pm SE) measured for Setesdal $(n=200)$ and Hol $(n=181)$ : A) Plant community properties, B) Soil properties. $* p<0.05$, $* * p<0.01$ and $* * * p<0.001$ (two-sample $t$-test).

\begin{tabular}{|c|c|c|c|c|c|c|c|c|}
\hline \multicolumn{9}{|l|}{ A } \\
\hline Site & $\begin{array}{c}\text { Vascular } \\
\text { plant } \\
\text { height }(\mathrm{cm})\end{array}$ & \multicolumn{2}{|c|}{$\begin{array}{c}\text { Vascular } \\
\text { plant cover } \\
(\%)\end{array}$} & $\begin{array}{l}\text { Cryptogam } \\
\text { cover }(\%)\end{array}$ & $\begin{array}{c}\text { Open soil } \\
(\%)\end{array}$ & \multicolumn{2}{|c|}{$\begin{array}{l}\text { Vascular } \\
\text { plant species } \\
\text { richness }\end{array}$} & $\begin{array}{l}\text { Lichen species } \\
\text { richness (total } \\
\text { per region) }\end{array}$ \\
\hline Setesdal & $\begin{array}{r}14.08 * * * \\
\pm 0.39\end{array}$ & \multicolumn{2}{|c|}{$\begin{array}{l}73.59 * * \\
\pm 0.97\end{array}$} & $\begin{array}{l}30.99 \\
\pm 1.54\end{array}$ & $\begin{array}{r}16.73 * * * \\
\pm 0.46\end{array}$ & \multicolumn{2}{|c|}{$\begin{array}{l}8.41 \\
\pm 0.16\end{array}$} & 5 \\
\hline Hol & $\begin{array}{l}9.40 \\
\pm 0.38\end{array}$ & \multicolumn{2}{|c|}{$\begin{array}{l}68.23 \\
\quad \pm 1.00\end{array}$} & $\begin{array}{r}53.29 * * * \\
\pm 1.75\end{array}$ & $\begin{array}{l}9.94 \\
\pm 0.85\end{array}$ & \multicolumn{2}{|c|}{$\begin{array}{l}12.2 * * * \\
\pm 0.54\end{array}$} & 11 \\
\hline \multicolumn{9}{|l|}{ B } \\
\hline Site & $\begin{array}{l}P(\mathrm{mg} / \\
100 \mathrm{~g})\end{array}$ & $\begin{array}{l}\mathrm{K}(\mathrm{mg} / \\
100 \mathrm{~g})\end{array}$ & $\begin{array}{c}\mathrm{Ca}(\mathrm{mg} / \\
100 \mathrm{~g})\end{array}$ & $\begin{array}{c}\mathrm{Mg}(\mathrm{mg} / \\
100 \mathrm{~g})\end{array}$ & $\begin{array}{c}\mathrm{Na}(\mathrm{mg} / \\
100 \mathrm{~g})\end{array}$ & $\mathrm{pH}$ & $\begin{array}{l}\text { DM (\%, } \\
\text { g/100 g) }\end{array}$ & $\begin{array}{l}\text { LOI (\%, } \\
\text { g/100 g) }\end{array}$ \\
\hline Setesdal & $\begin{array}{c}13.68 * * * \\
\pm 0.41\end{array}$ & $\begin{array}{r}42.50 * * * \\
\pm 1.14\end{array}$ & $\begin{array}{l}36.07 \\
\quad \pm 2.10\end{array}$ & $\begin{array}{c}21.21 * * * \\
\pm 0.97\end{array}$ & $\begin{array}{c}6.73 * * * \\
\pm 0.24\end{array}$ & $\begin{array}{l}4.41 \\
\quad \pm 0.02\end{array}$ & $\begin{array}{l}30.36 \\
\quad \pm 1.08\end{array}$ & $\begin{array}{c}70.35 * * * \\
\pm 1.97\end{array}$ \\
\hline Hol & $\begin{array}{l}6.05 \\
\pm 0.27\end{array}$ & $\begin{array}{l}13.81 \\
\pm 0.79\end{array}$ & $\begin{array}{r}49.10 * * \\
\pm 3.88\end{array}$ & $\begin{array}{l}8.45 \\
\pm 0.43\end{array}$ & $\begin{array}{l}2.48 \\
\quad \pm 0.11\end{array}$ & $\begin{array}{l}4.45 \\
\quad \pm 0.03\end{array}$ & $\begin{array}{c}62.37 * * * \\
\pm 1.28\end{array}$ & $\begin{array}{l}20.49 \\
\quad \pm 1.43\end{array}$ \\
\hline
\end{tabular}


TABLE 4. Relationship between bryophyte local abundance and regional distribution, and life history traits of each species within an A) acidic, oceanic region (Setesdal) and B) a base-rich, sub-continental region (Hol). The importance of traits was analyzed using linear regression (spore size, light, temperature, oceanity, humidity, acidity) and ANOVA (longevity, sexual reproduction, presence of gemmae, sexuality, presence of papillose leaf cell walls). Significant relationships are in bold. See Table 1 for more descriptions of life history traits.

A

\begin{tabular}{|c|c|c|c|c|c|c|c|c|c|c|c|c|}
\hline & \multicolumn{12}{|c|}{ Setesdal } \\
\hline & \multicolumn{6}{|c|}{ Local abundance } & \multicolumn{6}{|c|}{ Regional distribution } \\
\hline & $\mathrm{B}$ & SE & $F$ & $\mathrm{R}^{2}$ & $d f$ & $p$ & $\mathrm{~B}$ & SE & $F$ & $\mathrm{R}^{2}$ & $d f$ & $p$ \\
\hline Longevity & - & - & 8.84 & - & 2,45 & 0.005 & - & - & 5.00 & - & 2,45 & $\mathbf{0 . 0 3}$ \\
\hline Gemmae & - & - & 7.19 & - & 2,45 & 0.010 & - & - & 1.06 & - & 2,45 & 0.31 \\
\hline Sexuality & - & - & 3.10 & - & 2,45 & 0.085 & - & - & 0.57 & - & 2,45 & 0.45 \\
\hline Papillose & - & - & 1.47 & - & 2,48 & 0.230 & - & - & $<0.00$ & - & 2,48 & 0.98 \\
\hline Sexual reprod. & - & - & 0.34 & - & 2,47 & 0.560 & - & - & 0.09 & - & 2,45 & 0.75 \\
\hline Spore size & 0.070 & 0.080 & 0.75 & 0.016 & 1,45 & 0.390 & 0.012 & 0.100 & 0.01 & $<0.00$ & 1,45 & 0.91 \\
\hline Light index & 0.020 & 0.020 & 0.89 & 0.021 & 1,41 & 0.350 & -0.002 & 0.023 & 0.01 & $<0.00$ & 1,41 & 0.94 \\
\hline Temperature index & -0.005 & 0.045 & 0.02 & $<0.001$ & 1,38 & 0.900 & -0.057 & 0.050 & 1.28 & 0.033 & 1,38 & 0.27 \\
\hline Ocea.-cont. & 0.014 & 0.037 & 0.14 & 0.003 & 1,41 & 0.710 & 0.025 & 0.050 & 0.26 & 0.006 & 1,41 & 0.61 \\
\hline Humidity index & 0.037 & 0.017 & 4.41 & 0.091 & 1,44 & 0.042 & -0.030 & 0.023 & 1.28 & 0.028 & 1,44 & 0.26 \\
\hline Acidity-base index & -0.019 & 0.020 & 0.83 & 0.018 & 1,43 & 0.370 & -0.017 & 0.026 & 0.46 & 0.010 & 1,43 & 0.50 \\
\hline
\end{tabular}

Hol

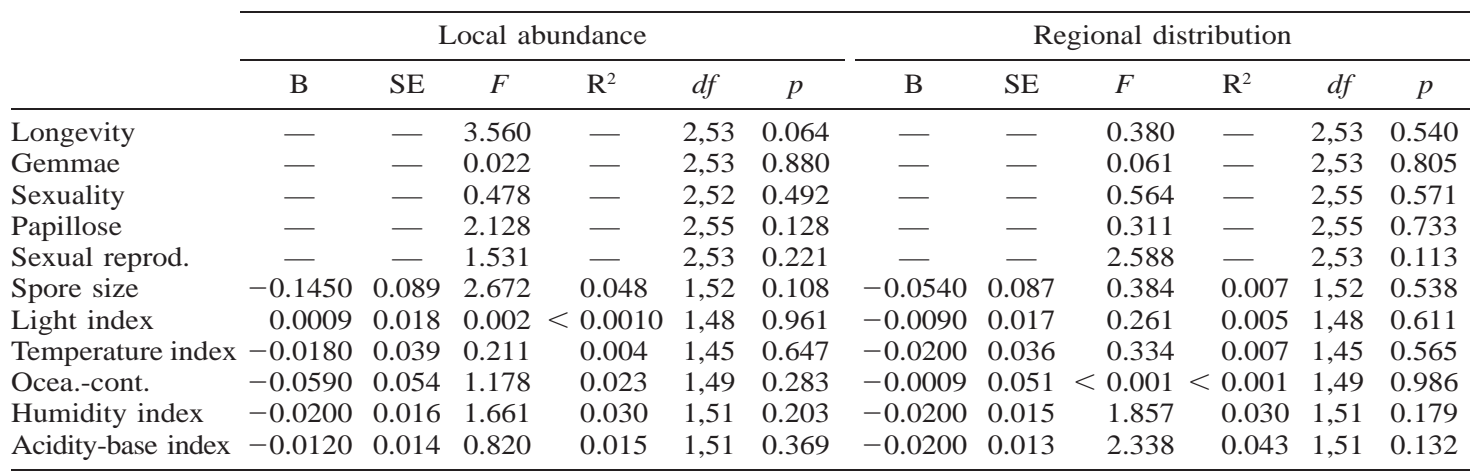

\pm 0.29), but differences were not significant (Table 3A). Calcium (Ca) was significantly higher at Hol as compared to Setesdal. Calcium correlated positively with $\mathrm{pH}$ at $\mathrm{Hol}(\mathrm{r}=0.43, p<0.001)$, but negatively with $\mathrm{pH}$ at Setesdal $(\mathrm{r}=-0.52, p<$ 0.001). Hol samples also had significantly higher soil moisture (high soil dry matter levels, and correspondingly low loss on ignition) compared to Setesdal, and high precipitation (like at Setesdal) might have caused leaching of Ca (Kinzel 1983; Økland 1996). Calcium is considered to be a key nutrient (cf. Økland \& Eilertsen 1993; Økland 1996), and higher Ca levels in Hol as compared to Setesdal suggest a higher productivity at the subcontinental, more base-rich site (Økland 1996), although other measured soil properties ( $\mathrm{P}, \mathrm{K}, \mathrm{Na}$, and $\mathrm{Mg}$ ) had higher values at Setesdal (Table 3B).

Trade-offs among life history traits. - The capacity to produce gemmae is negatively correlated with other means of reproduction, i.e., sexual reproduction $\left(\mathrm{r}=-0.39, \chi^{2}=7.23, p<0.01\right)$ and mean spore size $(\mathrm{r}=-0.34, p<0.001)$. In addition, gemmae producing species have a short life-span (negatively correlated to longevity; $r=-0.47, \chi^{2}$ $=9.39, p<0.005)$. Sexual reproduction is more common among monoicous species as compared to dioicous species $\left(\mathrm{r}=0.326, \chi^{2}=19.85, p<\right.$ $0.001)$. Longevity is positively correlated to spore size $(r=0.31, p=0.001)$. Temperature demand is positively correlated to both oceanic conditions ( $r$ $=0.38, p<0.001)$ and base-richness of soil $(\mathrm{r}=$ $0.26, p=0.014)$, and high temperature demands for bryophytes are negatively correlated to papillosity on leaf cell walls $(\mathrm{r}=-0.33, p<0.000)$.

Life history traits within region comparison.Bryophyte local abundance is significantly and positively correlated to longevity and dioecism (marginally non-significant), but negatively correlated with the ability to produce asexual propagules (gemmae) at Setesdal (Table 4A). All three traits showed marginally non-significant importance in a stepwise multiple regression, although longevity 
was the only significant variable using a backward elimination $(F=8.84$, df $=45, p=0.005)$. Bryophytes with a high humidity index correlated positively to species local abundance (Table 4A). Bryophyte longevity also correlated positively to regional distribution at Setesdal, but no other plant trait contributed significantly at the regional scale (Table 4A).

There were no significant linear relationships between bryophyte life history traits for the Hol species pool and their frequencies at a local or a regional scale, but longevity was nearly significant at the local scale (Table 4B).

Analyzing bryophyte trait-abundance using phylogentic independent contrasts (PIC) revealed similar but weaker correlations for the Setesdal data set. Spore size and oceanic conditions were negatively correlated (significantly and nearly significant, respectively) to local abundance at Hol using PIC, while all other traits at both scales showed weak correlations as for the analyses where phylogeny was not taken into account.

\section{DISCUSSION}

The relationship between bryophyte frequencies and their life history traits. - Data on quantitative life history traits are still limited for bryophytes, and although mostly qualitative traits were included in this study, several bryophyte traits with an obvious functional importance for bryophyte community patterns were identified in an oceanic, acidic, alpine environment (Setesdal). Long-lived bryophytes with a dioicous strategy (nearly significant) and high humidity indicator values were all successful at a local scale at Setesdal, while gemmae producing species had low success. However, no life history trait correlated significantly with bryophyte frequencies in the sub-continental, base-rich region ( $\mathrm{Hol})$, and as predicted; there were no preferences for bryophytes expressing specific traits.

These results are consistent with the trade-offs suggested by During (1992), which would classify bryophytes at Setesdal as tolerant species investing in long-term survival rather than sexual reproduction or asexual propagules (i.e., survives the difficult season as gametophore rather then spores or gemmae) (Grime et al. 1990). According to Longton (1988), the production of spores and specialized asexual propagules is highly restricted in severe (arctic and alpine) environments, and regeneration is thus mostly dependent on gametophore branching and fragmentation. Such regeneration processes are difficult to quantify, but vegetative reproduction is probably dominant for the majority of bryophytes at both sites, and the traits reflecting sexuality (spore size and commonness of sexual reproduc- tion) were not important in either region. However, the high local abundances of dioicous bryophytes at Setesdal provide indirect support for superior importance of vegetative reproduction at the oceanic site, since vegetative reproduction is more common among dioicous than monoicous species (Bates 1998; Hedderson \& Longton 1996). Differences in reproductive strategy between dioicous (vegetative) and monoicous (sexual) species are also supported by our correlations among traits that in addition show a trade-off between gemmae production and the two sexual traits; spore size and sexual reproduction.

Differences in species pool composition between regions. - The comparative study of bryophyte species pool composition between regions shows a shift in importance of climatic and edaphic factors. Oceanic conditions, temperature, and soil acidity did not structure bryophytes within regions, but could explain large scale differences in species pools between regions. Several oceanic species do not occur in the Hol species pool (e.g., Marsupella sphacelata, Mylia taylorii, Sphagnum subnitens) and base demanding species are not included in the Setesdal species pool (e.g., Campylium stellatum, Lescuraea incurvata, Mnium ambiguum, Tortula euryphylla). No bryophyte with high temperature demand is specifically identified for the oceanic region, although the temperature demand of the species pool was higher than for the sub-continental region. Only one (qualitative) trait correlated with differences in species pool composition between regions. A significantly greater number of species with the ability to reproduce sexually within the Setesdal species pool suggests that the oceanic environment supports sexual reproducing bryophytes, and humidity has also been identified as a major environmental factor for successful sexual reproduction (Longton \& Schuster 1983). Thus, even if species with vegetative reproduction seem to be more successful within this region, sexual reproducing species should have the potential to increase their abundances under favorable conditions.

The importance of dominant bryophyte life histories and environmental stress. - The contrasting results in the life history trait relationships for the two environmentally different alpine regions were not anticipated. However, a corresponding study on herbs in the same region has shown similar results. Vegetative reproduction (clonality) was significantly related to herb frequencies at Setesdal, while traits did not matter in Hol (Austrheim et al. 2005). The isolated importance of life history traits at Setesdal only indicates that severe environmental factors override the effects of environmental heterogeneity, and favor bryophytes able to tolerate environmental stress, while less tolerant life history 
strategies experience reduced frequencies. Grazing might contribute to vegetation homogenization for vascular plants on a regional scale (Frank 1998; Olff \& Ritchie 1998). Herbivores are also expected to decrease the cryptogam cover due to both trampling (large herbivores) and grazing (rodents) (Virtanen 2000; Virtanen et al. 1997). Our data indicates a significantly lower cryptogam cover at the oceanic region (mean 31\%) as compared to the subcontinental region (mean 53\%). Bryophytes are expected to have high densities in alpine regions especially if humidity is high (Longton 1988), and the low cryptogam cover in the oceanic region goes against our predictions. The most obvious explanation for limited bryophyte density would be sheep grazing pressure that has been high for several decades in the oceanic region (Setesdal), while sheep densities have been low in the sub-continental region (Hol). Jonsdottir (1991) found that grazing by sheep on Iceland increased the cover of a main forage plant (Carex bigelowii) due to lower competition from bryophytes that were destroyed by trampling. A similar change in competitive interaction between bryophytes and graminoids was found due to long-term grazing by lemmings and reindeer in NW Finland (Virtanen 2000). Two alternative strategies should be expected for bryophytes in a grazed environment. Firstly, several studies suggest grazing resistance to be an important strategy in arctic/alpine environments. Virtanen (2000) found bryophytes within the Polytrichaceae to be resistant to grazing in areas with lemming and reindeer, while bryophytes such as Dicranum spp., Pleurozium schreberi (Väre et al. 1996), and Polytrichum juniperinum (Helle \& Aspi 1983) were found to be resistant under heavy reindeer grazing. Dicranum spp., Pleurozium schreberi, and Polytrichastrum spp., (in addition to Barbilophozia lycopodioides and $B$. floerkei) were all among the species with the highest frequency, both at local and regional scales in Setesdal. At Hol, B. lycopodioides, Brachythecium reflexum, Dicranum scoparium, $P$. juniperinum, and Ptilidium ciliare were the most frequent species. Hence, grazing-resistant species (meaning both grazing and trampling resistant) could be found in the upper part of the rank-frequency curve in both regions (Appendix 1). Secondly, colonists and short-lived shuttle species would be expected to colonize gaps in grazed vegetation (During 1992). However, bryophytes with a colonization strategy (i.e., the opposite of a perennial strategy) appear to be unsuccessful in Setesdal as shown by the low abundances of gemmae producing colonists and sexual reproducing bryophytes, although open soil area is significantly higher at Setesdal as compared to Hol. A possible explanation for this is the low probability of small diaspores (i.e., spores and gemmae) to establish in stressful alpine environments (cf., Hassel \& Söderström 2003), while large diaspores such as shoot fragments are more effective in establishing new clones. In general, vegetative reproduction is found to be more common for plants in stressful habitats (de Kroon \& Groenendael 1997), and a negative impact of grazing on seed production has been reported (Edwards \& Crawley 1999; Fischer \& Wipf 2002). Data on grazing effects on bryophyte recruitment are scarce, but direct destructive effects (trampling) and indirect competitive effects from, for example graminoids are likely (Jonsdottir 1991). Alternative factors causing environmental stress should, however, not be omitted-acidic soils with low levels of calcium and $\mathrm{pH}$ (Roem et al. 2002). An experimental approach with grazing as the treatment is now established in both the oceanic, acidic region (2000) and the sub-continental, base-rich region (2001). Future studies are needed to clarify the ecological impact of grazing on bryophyte-life history trait relationships in the alpine region.

\section{ACKNOWLEDGMENTS}

We thank Inger E. Måren and Marianne Evju for help with collecting field data in Setesdal and Hol, respectively; Hans Blom for help with the determination of bryophytes; and Erika Leslie for help with soil analyses. Hans Blom, Urban Gunnarsson, Lars Söderström, Richard Strimbeck, and two anonymous referees provided helpful comments on previous versions of this manuscript. The study was mainly financed by the Research Council of Norway, project no. 134361/720.

\section{Literature Cited}

Austrheim, G., M. Evju \& A. Mysterud. 2005. Herb abundance and life history traits in two contrasting alpine habitats in southern Norway. Plant Ecology 141: (in press).

BAtES, J. W. 1995. Numerical analysis of bryophyte-environment relationships in a lowland English flora Fragmenta Floristica et Geobotanica 40: 471-490.

1998. Is life-form a useful concept in bryophyte ecology? Oikos 82: 223-237.

Brown, J. 1995. Macroecology. University of Chicago Press, Chicago, IL.

Buck, W. R. \& B. Goffinet. 2000. Morphology and classification of mosses, pp. 71-123. In A. J. Shaw \& B Goffinet (eds.), Bryophyte Biology. Cambridge University Press, Cambridge.

Cox, C. J., B. Goffinet, A. E. Newton, A. J. Shaw \& T. A. J. Hedderson. 2000. Phylogenetic relationships among the diplolepideous-alternate mosses (Bryidae) inferred from nuclear and chloroplast DNA sequences. The Bryologist 103: 224-241.

Crandall-Stotler, B. \& R. E. Stotler. 2000. Morphology and classification of the Marchantiophyta, pp. 2170. In A. J. Shaw \& B. Goffinet (eds.), Bryophyte Biology. Cambridge University Press, Cambridge.

DAMShOLT, K. 2002. Illustrated Flora of Nordic Liver- 
worts and Hornworts. Nordic Bryological Society, Lund.

De Kroon, H. \& J. M. Van Groenendael. 1997. The Ecology and Evolution of Clonal Plants. Backhuys, Leiden.

De Luna, E., W. R. Buck, H. Akiyama, T. Arikawa, H. Tsubota, D. Gonzalez, A. E. Newton \& A. J. Shaw. 2000. Ordinal phylogeny within the hypnobryalean pleurocarpous mosses inferred from cladistic analyses of three chloroplast DNA sequence data sets: $\operatorname{trn} \mathrm{L}-\mathrm{F}$, $r p s 4$, and $r b c$ L. THE BRYOlOGIST 103: 242-256.

DüLL, R. 1991. Zeigerwerte von Laub- und Lebermoosen. Scripta Geobotanica 28: 175-214.

DuRING, H. J. 1992. Ecological classification of bryophytes and lichens, pp. 1-31. In J. W. Bates \& A. M. Farmer (eds.), Bryophytes and Lichens in a Changing Environment. Oxford University Press, Oxford.

EDWARDS, G. R. \& M. J. CRAWLEY. 1999. Herbivores, seed banks and seedling recruitment in mesic grassland. Journal of Ecology 87: 423-435

EllenberG, H., H. E. Weber, R. Düll, V. Wirth, W Werner \& D. PAUlissen. 1991. Zeigerwertevon pflantzen in Mitteleuropa. Scripta Geobotanica XVIII: $1-248$.

FISHER, M. \& S. WIPF. 2002. Effect of low-intensuty grazing on the species-rich vegetation of traditionally mown subalpine meadows. Biological Conservation 104: 1-11.

FRANK, D. A. 1998. Ungulate regulation of ecosystem processes in Yellowstone National Park: direct and feedback effects. Wildlife Society Bulletin 26: 410-418.

FRISVOLL, A. A. 1996. Habitatoversikt for norske mosar, med kategoriar og trugsmål for trua artar. NINA Oppdragsmelding 441: 1-37.

. 1997. Bryophytes of spruce forest stands in Central Norway. Lindbergia 22: 83-97.

- A. Elvebakk, K. I. Flatberg \& R. H. ØKland. 1995. Sjekkliste over norske mosar. Vitenskapeleg og norsk namnverk. NINA Temahefte 4: 1-104.

Førland, E. J. 1993. Nedbørsnormaler, normalperiode 1961-1990. Norwegian Metrological Institute 39: 163.

Gignac, L. D., D. H. VitT \& S. E. Bayley. 1991. Bryophyte response surfaces along ecological and climatic gradients. Vegetatio 93: 29-45.

Grime, J. P. 1979. Plant Strategies and Vegetation Processes. Chichester, Wiley.

Grime, J. P., E. R. RinCON \& B. E. WiCKERSON. 1990. Bryophytes and plant strategy theory. Botanical Journal of the Linnean Society 104: 175-186.

Grolle, R. \& D. G. Long. 2000. An annotated check-list of the Hepaticae and Anthocerotae of Europe and Macaronesia. Journal of Bryology 22: 103-140.

HallingBäck, T. 1996. The Bryophytes of Sweden and Their Ecology. Artdatabanken SLU, Uppsala.

Harvey, P. H. \& M. D. PAgel. 1991. The Comparative Method in Evolutionary Biology. Oxford University Press, Oxford.

Hassel, K., B. Pedersen, \& L. Söderström. 2005. Changes in life-history traits in an expanding moss species: Phenotypic plasticity or genetic differentiation? A reciprocal transplantation experiment with $\mathrm{Po}$ gonatum dentatum. Ecography 28: 71-80.

\& L. SÖDERSTRÖM. 2003. Life history variation of Pogonatum dentatum (Brid.) Brid. in contrasting habitats. Journal of the Hattori Botanical Laboratory 93: 215-222.

Hedderson, T. A. \& R. E. Longton. 1996. Life history variation in mosses: water relations, size and phylogeny. Oikos 77: 31-43

HeEgaARD, E. 2002. A model of alpine species distribution in relation to snowmelt time and altitude. Journal of Vegetation Science 13: 493-504.

Helle, T. \& J. Aspi. 1983. Effects of winter grazing by reindeer on vegetation. Oikos 40: 337-343.

Holtedahl, O. 1969. Geology of Norway. Norges Geologiske Undersøkelse 208: 1-540.

Hutchinson, G. 1957. Concluding remarks. Cold Spring Harbor Symposia on Quantitative Biology 22: 415427.

Ives, K. H. \& J. D. GibBons. 1967. A correlation measure for nominal data. American Statistics 21: 16-17.

JónsDótTIR, I. S. 1991. Effects of grazing on tiller size and population dynamics in a clonal sedge (Carex bigelowii). Oikos 62: 177-188.

KINZEL, H. 1983. Influence of limestone, silicates and soil pH on vegetation, pp. 201-244. In O. L. Lange, P.S. Nobel, C.B. Osmond \& H. Ziegler (eds.), Physiological Plant Ecology III. Responses to the Chemical and Biological Environment. Springer-Verlag, Berlin.

KöRnER, C. 1999. Alpine Plant Life. Functional Plant Ecology of High Mountain Ecosystems. Springer, Berlin.

Krogstad, T. 1992. Metoder for jordanalyser. Institutt for jordfag, Rapport 6: 1-32.

La Farge, C., B. D. Mishler, J. A. Wheeler, D. P. Wall, K. Johannes, S. Schaffer \& A. J. Shaw. 2000. Phylogenetic relationships within the haplolepideous mosses. THE BRYOLOGIST 103: 257-276.

Longton, R. E. 1988. Biology of Polar Bryophytes and Lichens. Cambridge University Press, Cambridge.

- \& R. M. SChUSTER. 1983. Reproductive Biology, pp. 386-462. In R. M. Schuster (ed.), New Manual of Bryology. Hattori Botanical Laboratory, Nichinan.

MARTINS, E. P. 2003. COMPARE, version 4.5. Computer programs for the statistical analysis of comparative data. Distributed by the author at http://compare.bio. indiana.edu/. Department of Biology, Indiana University, Bloomington, IN.

Moles, A. T. \& M. Westoby. 2002. Seed addition experiments are more likely to increase recruitment in larger-seeded species. Oikos 99: 241-248.

Newton, A. E., C. J. Cox, J. G. Duckett, J. A. Wheeler, B. Goffinet, T. A. J. Hedderson \& B. D. Mishler. 2000. Evolution of the major moss lineages: Phylogenetic analyses based on multiple gene sequences and morphology. THE BRYOLOGIST 103: 187-211.

NyноLM, E. 1987. Illustrated Flora of Nordic Mosses. Fasc. 1. Fissidentaceae-Seligeriaceae. Nordic Bryological Society, Lund.

1989. Illustrated Flora of Nordic Mosses. Fasc. 2. Pottiaceae-Splachnaceae-Schistostegaceae. Nordic Bryological Society, Lund.

. 1993. Illustrated Flora of Nordic Mosses. Fasc. 3. Bryaceae-Rhodobryaceae-Mniaceae-Cinclidiaceae-Plagiomniaceae. Nordic Bryological Society, Lund.

. 1998. Illustrated Flora of Nordic Mosses. Fasc. 4. Aulacomniaceae-Meesiaceae-Catoscopiaceae-Bartramiaceae-Timmiaceae-Encalyptaceae-Grimmiaceae-Hedwigiaceae-Orthotrichaceae. Nordic Bryological Society, Lund.

ØKLAND, R. H. \& O. EILERTSEN. 1993. Vegetation-environment relationships of boreal coniferous forests in the Solhomfjell area, Gjerstad, S Norway. Sommerfeltia 16: $1-254$

ØKLAND, T. 1996. Vegetation-environment relationships of 
boreal spruce forests in ten monitoring reference areas in Norway. Sommerfeltia 22: 1-349.

OlfF, H., \& M. E. RitchiE. 1998. Effects of herbivores on grassland plant diversity. Trends Ecology and Evolution 13: 261-265.

READER, R. J. 1998. Relationship between species relative abundance and plant traits for an infertile habitat. Plant Ecology 134: 43-51.

Roem, W. J., H. Klees \& F. Berendse. 2002. Effects of nutrient addition and acidification on plant species diversity and seed germination in heathland. Journal of Applied Ecology 39: 937-948.

Shaw, A. J. 2000. Phylogeny of the Sphagnopsida based on chloroplast and nuclear DNA sequences. THE BRYOLOGIST 103: 277-306.

Shaw, A. J. \& B. Goffinet (Eds.). 2000. Bryophyte Biology. Cambridge University Press, Cambridge.

Sigmond, E. 1998. Odda Berggrunnskart; Odda; 1:250 000. Norges geologiske unders $\varnothing$ kelse, Trondheim.

Smith, A. J. E. 1978. The Moss Flora of Britain and Ireland. Cambridge University Press, Cambridge.

STÖRMER, P. 1969. Mosses with a western and southern distribution in Norway. Universitetsforlaget, Oslo.

VAnderpoorten, A. \& P. Engels. 2002. The effects of environmental variation on bryophytes at a regional scale. Ecography 25: 513-522.
VÄRe, H., R. Ohtonen \& K. Mikкola. 1996. The effect and extent of heavy grazing by reindeer in oligotrophic pine heaths in northeastern Fennoscandia. Ecography 19: 245-253.

VeVLE, O. 1999. Ellenbergs $\varnothing$ kologiske faktortal. Liste for moser og lav utarbeidet for norske forhold. Unpubl. Http://fag.hit.no/af/nv/nvlink/flora/hit1mos141299.htm

VIRTANEN, R. 2000. Effects of grazing on above-ground biomass on a mountain snowbed, NW Finland. Oikos 90: 295-300.

, P. A. Lundberg, J. Moen \& L. Oksanen. 1997. Topographic and altitudinal patterns in plant communities on European arctic islands. Polar Biology 17: 95-113.

Westoby, M., M. Leishman \& J. Lord. 1997. Comparative ecology of seed size and dispersal, pp. 143-162. In J. Silvertown, M. Franco \& J. Harper (eds.), Plant Life Histories: Ecology, Phylogeny, and Evolution. Cambridge University Press, Cambridge.

YATES, F. 1934. Contingency tables involving small numbers and the $\chi^{2}$ test. Journal of Royal Statististics Society Supplement 1: 217-235.

ms. received June 11, 2004; accepted Jan. 10, 2005. 


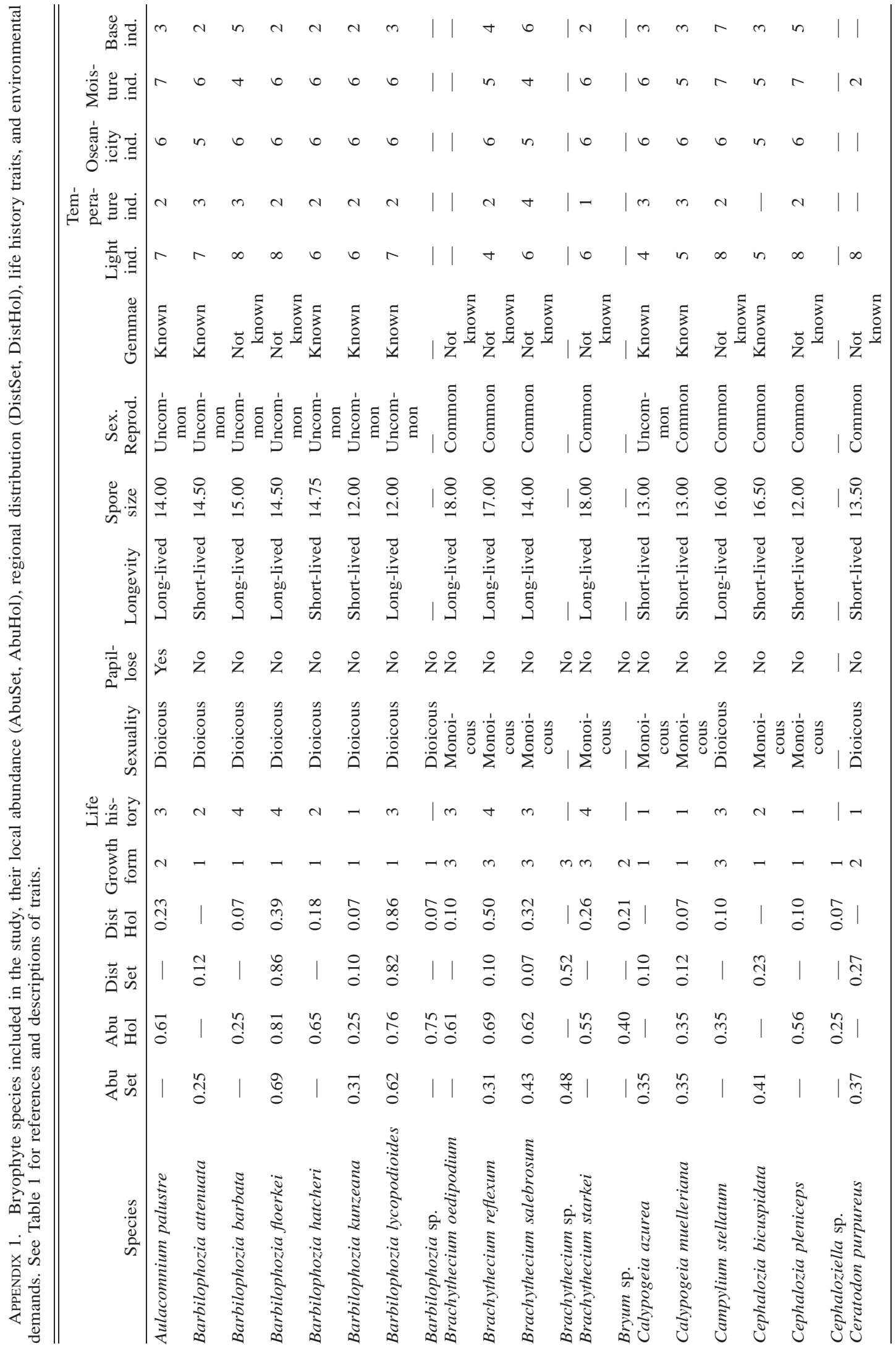




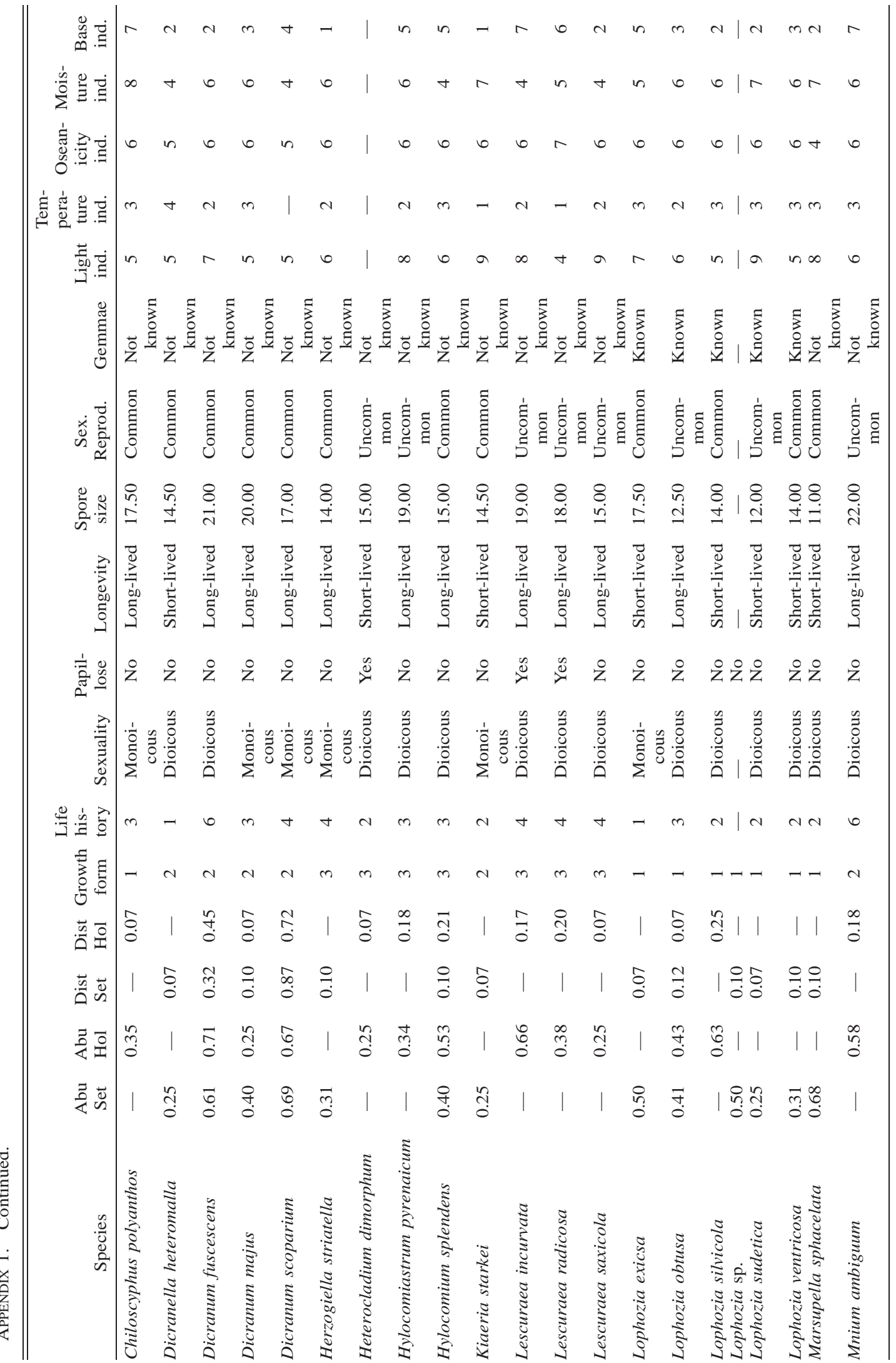




\begin{tabular}{|c|c|c|c|c|c|c|c|c|c|c|c|c|c|c|c|c|c|c|c|}
\hline $\begin{array}{l}0 \\
\tilde{a} \\
\ddot{n} . \dot{\Xi}\end{array}$ & 0 & -- & $n$ & $n$ & 0 & $r$ & in & $n$ & t & N & n & N & N & N & N & $\mid v$ & $m$ & $N$ & - \\
\hline$\dot{n}$ & 0 & 06 & $\infty$ & $\infty$ & 6 & $\nabla$ & 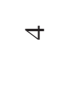 & 0 & $r$ & t & in & ナ & 0 & 0 & $r$ & - & t & N & 6 \\
\hline 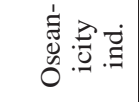 & 0 & no & 0 & 0 & $n$ & $n$ & $\nabla$ & $n$ & I & 0 & $n$ & 0 & 0 & in & 0 & 6 & | & $n$ & 0 \\
\hline 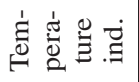 & 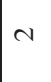 & $N-$ & $m$ & $m$ & $\nabla$ & $m$ & 1 & $m$ & $m$ & $m$ & I & | & - & N & 4 & $\mid N$ & $N$ & $N$ & $N$ \\
\hline 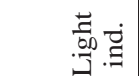 & in & rn & | & I & ナ & 0 & in & $\nabla$ & I & 0 & + & in & r & $\nabla$ & $\infty$ & 0 & $\infty$ & $a$ & $\infty$ \\
\hline 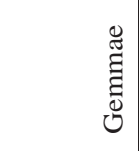 & $\ddot{z}$ & 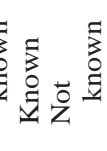 & & 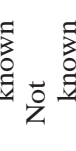 & 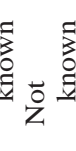 & z & 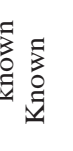 & 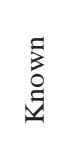 & $\mathrm{z}^{\stackrel{5}{0}}$ & $\begin{array}{l}5 \\
0 \\
0 \\
0\end{array}$ & $\begin{array}{l}5 \\
0 \\
0\end{array}$ & $\begin{array}{l}5 \\
0 \\
0 \\
0\end{array}$ & 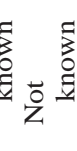 & 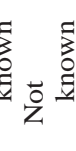 & 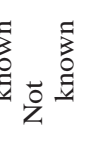 & & $z^{\frac{5}{3}}$ & & 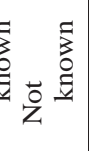 \\
\hline 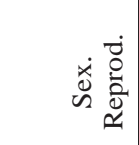 & 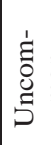 & 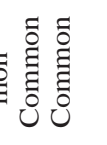 & $\begin{array}{l}\text { हू } \\
\text { हू } \\
\text { ठ் }\end{array}$ & $\begin{array}{l}\tilde{0} \\
\text { छี } \\
\text { ठ }\end{array}$ & 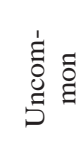 & 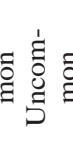 & 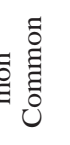 & $\begin{array}{l}\text { ฮี } \\
\text { घี } \\
\text { U }\end{array}$ & 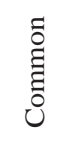 & $\begin{array}{l}\tilde{0} \\
\stackrel{\Xi}{\Xi} \\
0\end{array}$ & $\begin{array}{l}\tilde{0} \\
\stackrel{\Xi}{\Xi} \\
0\end{array}$ & $\begin{array}{l}\tilde{0} \\
\text { हี } \\
\text { ठ் }\end{array}$ & $\begin{array}{l}\tilde{0} \\
\text { ีี } \\
0\end{array}$ & $\begin{array}{l}\tilde{\Xi} \\
\text { ี̇ } \\
\text { ப் }\end{array}$ & 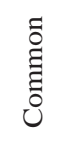 & | & 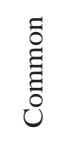 & 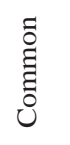 & 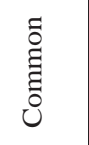 \\
\hline $\begin{array}{l}0 \\
\text { : } \\
\text { के }\end{array}$ & $\frac{n}{n}$ & $\begin{array}{l}88 \\
0.0 \\
9\end{array}$ & $\begin{array}{l}8 \\
\text { in }\end{array}$ & $\begin{array}{l}8 \\
\stackrel{1}{n}\end{array}$ & $\begin{array}{l}8 \\
\text { i }\end{array}$ & $\begin{array}{l}8 \\
\text { I }\end{array}$ & $\underset{8}{\stackrel{8}{~}}$ & $\begin{array}{l}8 \\
\ddot{-}\end{array}$ & $\begin{array}{l}8 \\
\ddot{-}\end{array}$ & $\begin{array}{l}8 \\
\infty \\
\infty \\
-\end{array}$ & $\frac{8}{\dot{4}}$ & $\begin{array}{l}\text { \&े } \\
\dot{\vec{\lambda}}\end{array}$ & $\begin{array}{l}8 \\
\stackrel{0}{-}\end{array}$ & $\begin{array}{l}8 \\
\dot{ \pm}\end{array}$ & $\begin{array}{l}\stackrel{n}{n} \\
\text { ñ }\end{array}$ & $\underset{\Xi}{\stackrel{\Xi}{-}}$ & $\begin{array}{l}8 \\
\stackrel{0}{0}\end{array}$ & $\begin{array}{l}8 \\
\dot{+}\end{array}$ & $\begin{array}{l}8 \\
\stackrel{0}{-}\end{array}$ \\
\hline $\begin{array}{l}\overrightarrow{2} \\
5 \\
0.0 \\
0 \\
0 \\
-\end{array}$ & 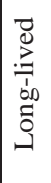 & 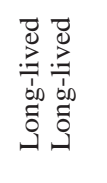 & 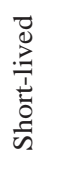 & 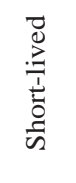 & 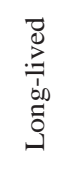 & 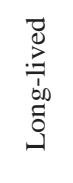 & $\begin{array}{l}\overrightarrow{0} \\
\stackrel{.}{7} \\
00 \\
0 \\
0 \\
.1\end{array}$ & 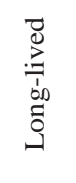 & 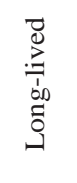 & 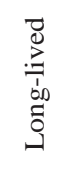 & $\begin{array}{l}\overrightarrow{0} \\
\stackrel{0}{1} \\
\frac{0}{0}\end{array}$ & 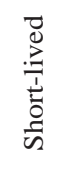 & 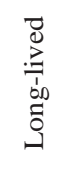 & $\begin{array}{l}\overrightarrow{0} \\
\sum_{1} \\
0 \\
0 \\
0 \\
.1\end{array}$ & 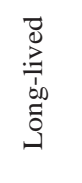 & 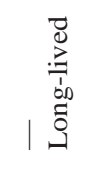 & $\begin{array}{l}\vec{D} \\
\stackrel{D}{1} \\
\overline{0} \\
\bar{D}\end{array}$ & $\begin{array}{l}\overrightarrow{0} \\
\stackrel{0}{1} \\
0 \\
0 \\
0 \\
.1\end{array}$ & 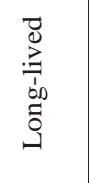 \\
\hline 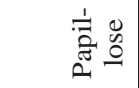 & $\stackrel{0}{z}$ & żz & $\stackrel{\circ}{z}$ & $\stackrel{\circ}{z}$ & $\stackrel{\circ}{z}$ & $\stackrel{\circ}{z}$ & $\stackrel{\circ}{z}$ & $\stackrel{0}{z}$ & ż & $\stackrel{8}{z}$ & ż & ż & $\sum_{\nu}^{\infty}$ & $\stackrel{0}{0}$ & $\sum_{\nu}^{\infty}$ & $\sum_{i=1}^{\infty}$ & $\stackrel{\infty}{\infty}$ & $\stackrel{0}{0}$ & $\stackrel{\infty}{\approx}$ \\
\hline 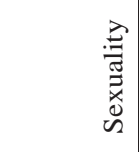 & 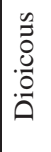 & 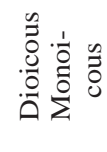 & & 1 & 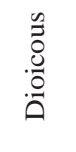 & $\begin{array}{l}0 \\
0 \\
.0 \\
0\end{array}$ & 宽 & 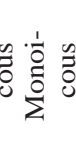 & 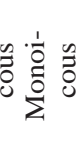 & 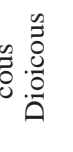 & 1 & 遂 & 莞 & 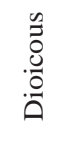 & $\begin{array}{l}\mathscr{0} \\
\tilde{0} \\
\frac{0}{0} \\
\stackrel{0}{0}\end{array}$ & 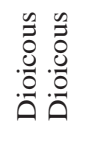 & $\begin{array}{l}0 \\
0 \\
.00 \\
0 \\
0\end{array}$ & 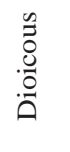 & 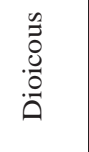 \\
\hline$\oiiint \dot{y}$ & 0 & +0 & - & - & $m$ & $\nabla$ & $m$ & $m$ & $m$ & $m$ & - & - & 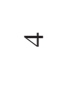 & $m$ & 0 & m & $\mathrm{N}$ & 6 & $n$ \\
\hline $\begin{array}{l}5 \\
0 \\
0 \\
0\end{array}$ & N & $-c$ & - & - & - & - & $n$ & $m$ & $m$ & $m$ & $N$ & N & N & $N$ & N & $\mathrm{NN}$ & $N$ & $N$ & $N$ \\
\hline 虽完 & @़ & | & $\stackrel{0}{\circ}$ & 1 & $\stackrel{0}{\circ}$ & o. & $\stackrel{n}{0}$ & I & $\stackrel{5}{0}$ & $\stackrel{n}{?}$ & $\stackrel{m}{0}$ & 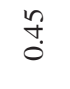 & $\tilde{3}$ & 1 & I & $\stackrel{\hat{\jmath}}{0}$ & $\stackrel{1}{i}$ & $\stackrel{5}{0}$ & $\frac{\infty}{0}$ \\
\hline $\begin{array}{ll}\vec{n} & \vec{D} \\
\overrightarrow{0} & 0\end{array}$ & 1 & $\underset{0}{\tilde{O}}$ & $\stackrel{0}{0}$ & I & 1 & 1 & 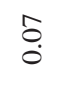 & $\hat{n}$ & I & $\stackrel{m}{0}$ & 1 & $\tilde{n}$ & $\stackrel{\text { I }}{0}$ & $\frac{0}{0}$ & $\frac{0}{0}$ & $\begin{array}{l}0 \\
0 \\
0 \\
0\end{array}$ & $\stackrel{\hat{o}}{0}$ & $\stackrel{1}{0}$ & @̊ \\
\hline 总完 & $\stackrel{m}{0}$ & $1 \stackrel{0}{n}$ & $\stackrel{n}{0}$ & 1 & $\stackrel{1}{\infty}$ & $\stackrel{n}{n}$ & $\stackrel{n}{n}$ & 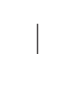 & $\stackrel{n}{\pi}$ & $\stackrel{\text { to }}{0}$ & $\stackrel{n}{n}$ & F. & $\tilde{0}$ & 1 & I & $\mid \stackrel{\substack{\infty \\
0}}{0}$ & i & in & $\stackrel{1}{0}$ \\
\hline $\overrightarrow{0}$ & 1 & $\stackrel{m}{+} \mid$ & $\stackrel{n}{n}$ & | & 1 & 1 & $\stackrel{n}{n}$ & ñ & 1 & $\begin{array}{l}\infty \\
0 \\
0\end{array}$ & 1 & $\stackrel{\infty}{m}$ & $\begin{array}{l}\stackrel{8}{0} \\
0\end{array}$ & $\stackrel{n}{a}$ & $\stackrel{\pi}{0}$ & $\begin{array}{l}n \\
m \\
\infty \\
0\end{array}$ & $\stackrel{n}{n}$ & ָे & $\begin{array}{l}\bar{\sigma} \\
0\end{array}$ \\
\hline$\stackrel{0}{0}$ & 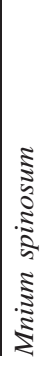 & 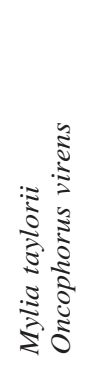 & $\begin{array}{l}\dot{0} \\
\dot{3} \\
\stackrel{\Xi}{0} \\
2\end{array}$ & $\begin{array}{l}\dot{2} \\
\stackrel{0}{\Xi} \\
0\end{array}$ & 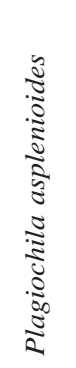 & 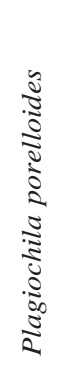 & 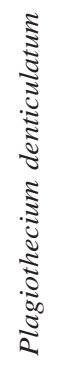 & 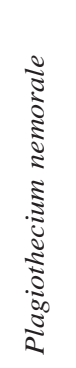 & 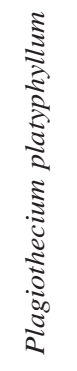 & 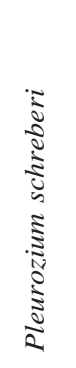 & 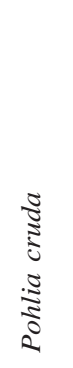 & 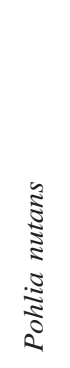 & 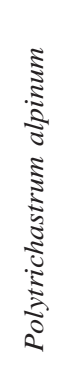 & 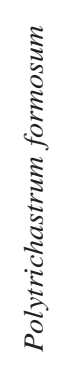 & 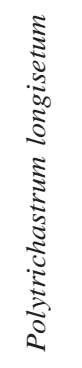 & 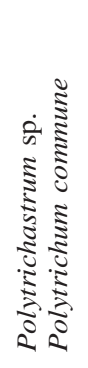 & 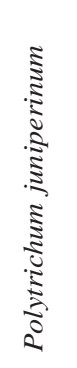 & 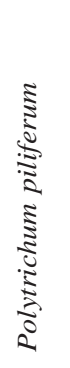 & 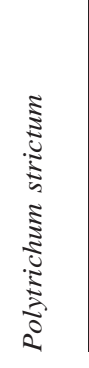 \\
\hline
\end{tabular}




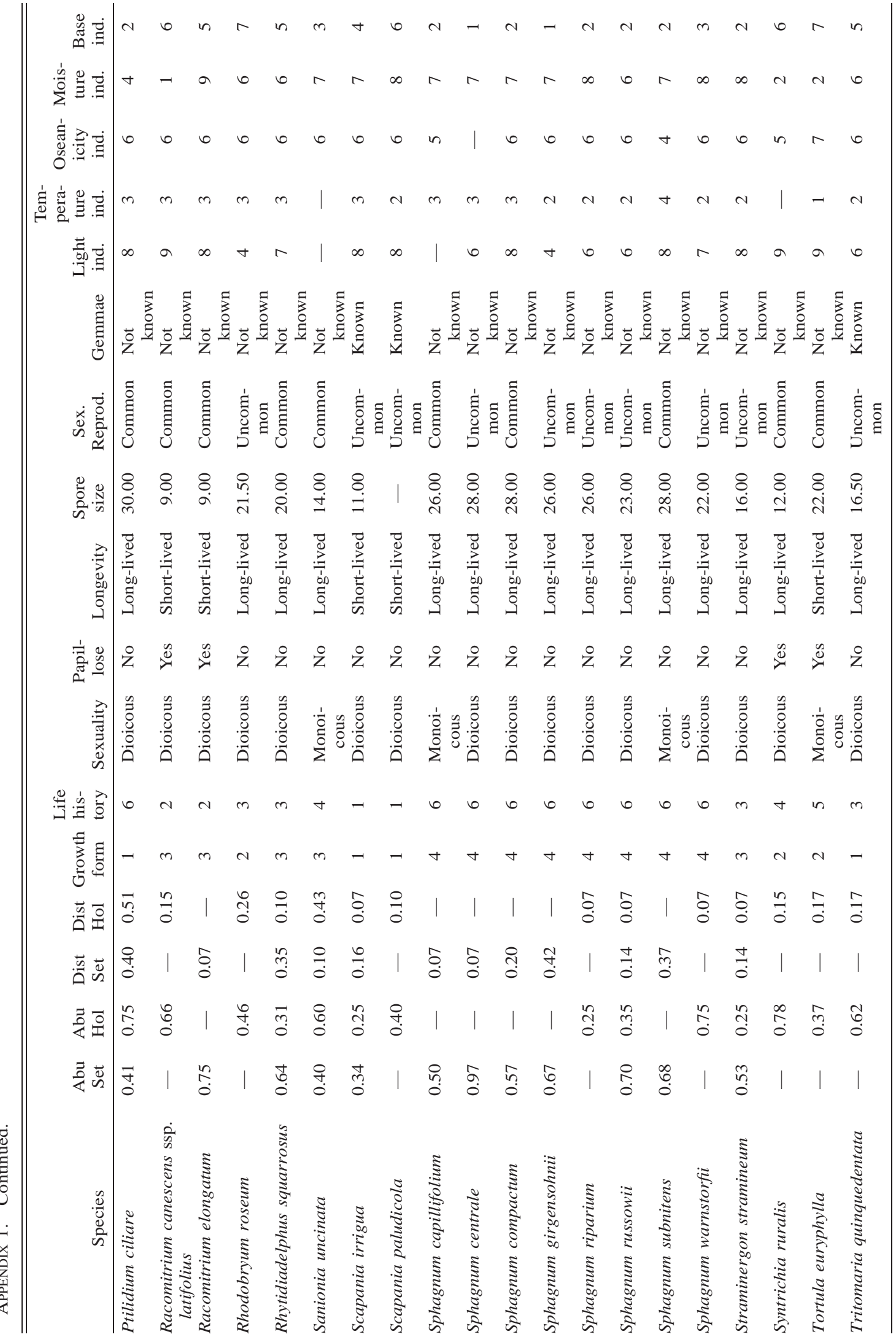

